

\section{Usage of Social Media in City Marketing: A Research on 30 Metropolitan Municipalities in Turkey*}

\section{Niyazi Gümüş}

\section{Introduction}

Social media has directly or indirectly affected many fields since its emergence. Social media channels having billions of users today have added a new meaning to the concept of communication. Today, the brands, companies, public enterprises, celebrities, nongovernmental organizations as well as the individuals are taking part on social media. One of the fields that social media directly affects and contributes is certainly city marketing activities. By the social media, tens of cities had the opportunity of announcing their historical, cultural and touristic characteristics to a wide audience. The cities, in the name of their public enterprises and touristic locations, have reached to hundreds of thousands of followers through the accounts opened on social media channels. They had the opportunity of directly or indirectly communicating their touristic values to millions of people through their followers and their sharings. Moreover, the visuals prepared by the specialists in the field are also reaching to hundreds of thousands of people through these social media channels. When the intense competition among the cities is considered, this opportunity provided by social media is extremely important.

Within the scope of this study that is realized in order to learn the social media usage statuses of 30 metropolitan municipalities in Turkey in the city marketing activities, findings relevant to presence of metropolitan municipalities in social media accounts, their follower numbers and number of their sharings regarding publicity have been revealed.

\section{City Marketing}

The strong competition that emerges in all the fields today has also covered the cities, and it has obliged them to perform marketing operations in order to attract more tourists and investors against other cities. In this

* This study was presented at the 1st International Congress of Management Economy and Policy, 26-27 November 2016. direction, the marketing activities have started to be realized mostly by the local managers, companies and inhabitants of the city who are the main actors of city marketing. Within this scope, city marketing is being defined as efforts for showing others why these actors love this city (Kavaratzis and Ashworth, 2007). In another definition, it is being defined as the efforts for increasing the economic and social functions and thus the attractiveness of the city in the direction of the demands of the target audience (Carrasquillo, 2011). City marketing, which is being considered as a long-termed process, is being defined as efforts to meet the requirements of the visitors, investors and inhabitants of the city. Within this scope, it is being suggested to carry out marketing activities on issues such as entertainment, recreation, security, employment, settlement facilities, trade, transportation, education, city order, infrastructure etc. (Goowaerts et al., 2014). Other reasons directing the cities to city marketing activities due to the competition arising among the cities are being listed as follows (Altunbas, 2007):

- Attracting the tourists and visitors

- Attracting business from other cities

- Carrying out and improving the current business

- Growing small business and opening new ones

- Increasing export and investments

- Increasing the population and enabling distribution within

When the above articles are examined, it is being observed that the cities involve in marketing activities for economic and social reasons. In the process of city marketing, the requirements of arranging the infrastructure and social view of the city, determining common objectives, forming the development agenda and action plans that will pave the way for common vision, revealing the current potential of the city, increasing sharing and communication, forming the common city vision and values, enabling the decisions to be made jointly along with extensive reconciliation by integrating the views shouldn't be forgotten in order to attain the above purposes. In the general sense, Turkish cities have historical, cultural and touristic values which are valuable than the other. But by versatile marketing efforts, it shouldn't be forgotten that millions of tourists may be attracted even for a few number of touristic products. The element required to be performed at this point is the initiation of marketing activities by the local managers of the city along with the stakeholders through modern marketing tools and approaches. 


\section{Social Media}

Social media is known as the common name of hundreds of channels such as Facebook, Twitter, Instagram, YouTube etc. which had emerged as web 2.0 applications. Social media, with its user numbers, is standing as a channel in which all parts either seeking profit or not as brands and companies being in the first place take place and are required to take place. In the evaluations performed regarding social media, it is being expressed as technology based applications allowing the users to generate information and to share such information (Kaplan and Haenlein, 2010). In another study, when the social media is used by public institutions, it is being assessed as an innovative platform allowing the institutions to interact with citizens and other institutions (Criado et al., 2013). It is easily specified that the social media, which had emerged along with the improvements arising in communication technologies in the recent ten years, is shaping and transforming the marketing activities (Gulbahar and Yildırım, 2015). If we consider the user numbers of social media channels that come to the forefront in the general sense, it is being observed that Facebook has 1.650 million and Twitter has 500 million users by September 2016 (www.socialbakers.com, 2016). And if we consider the social media figures in Turkey, about 46 millions of Turkish population - which had exceeded 79 millions by January 2016- are active internet users. Also, the total number of social media users in Turkey is estimated as about 42 millions (Wearesocial, 2016). Social media is intensely being used in tourism sector and thus in city marketing activities as in each field. Social media platforms such as Facebook, Instagram, Twitter, Blogs, forums and media sharing sites are providing facilities for both the stakeholders of tourism and the city managers on issues such as improving the images of touristic locations, making the past or future tourism plans and establishing direct communication with the touristic locations. The main reason of this is the continuous use of social media by the people before planning their travels, in the process of travel and by the end of their travel at the point of sharing their experiences regarding their travel. For this reason, social media tools are being considered as effective means in the publicity of touristic locations (Ketter, 2016).

\section{Usage of Social Media in City Marketing}

Along with city marketing or marketing of locations, frequent magazines, newspapers and city presentation videos are also used. But these unidirectional means of communication were over costly and remained very limited in getting feedback from the target audience and in interacting with the target audience along with increasing popularity of the cities (Zhou and Wang, 2014). But by virtue of social media, interaction in between the city and the target audience, receipt of instant feedback, sharing opinions mutually and sharing visual and written items regarding the city have become possible. Social media is now very effective on city marketing, especially as destination of tourism. Social media is providing a suitable platform for improving and sharing the experiences of the ones visiting the city. The integrated use of other social media channels relevant to tourism by the local managers will definitely increase the effect of activities (Zhou and Wang, 2014). Through the social media, the city administrations are able to initiate discussions with different target audiences and are able to obtain the opinions of target audience rapidly (Howard, 2012). This condition will provide significant advantages to managers compared to the traditional media tools.

Social media, besides being a platform providing followers the opportunity of communicating with each other, also provides the followers the chance of directly reaching the opinions and suggestions of public institutions which have a page (Mossberger, 2013). Because, it is known that personal experiences and interactions are affecting the perception of the individuals regarding the city (Sevin, 2014). By the social media, the opinions of ones which had previously visited the relevant cities and the suggestions of the public institutions relevant to the touristic product are directly learned.

Social media is used in planning travels and in searching travel information, and briefly as a field of tourism (Xiang and Gretzel, 2010; Jacobsen and Munar, 2012). Moreover, it will be possible to reach to a wider audience through sharing of texts and visuals -relevant to events that will be organized in the city- by the municipalities, and thus the attention of hundreds of thousands of people will be drawn (Calisir, 2015). For this reason, the use of social media in city marketing activities is standing inevitably. For instance, by the claim that the Sirince Village of Izmir will not be affected from doomsday in 2012, it had become the most known village of the world (Bozkurt, 2013). This condition shows the power of social media. In a research performed on social media accounts of 31 cities in the world, it had been found out that Twitter, YouTube and Facebook are the most used social media channels by the city municipalities (Mainka et al., 2014). In a research regarding the social media implementations of metropolitan municipalities, it had been determined that only 9 out of 16 metropolitan municipalities operating in Turkey are using social media in corporate sense. In the same study, it had been determined that the metropolitan municipalities are mainly tweeting regarding the issues of transportation, service, infrastructure, events and social municipalism, and that very few municipalities are using social media for publicity of cities (Tarhan, 2012).

Being a recognized or known city means becoming more valuable and preferable in the eyes of ones living in 
that city and sightseeing the city (Iri and et al., 2011). Today, everyone will accept that the most suitable means both affordability and reachability in increasing the recognition of the cities and in making it reach to large masses in social media. For this reason, the local managers not using this channel in the process of city marketing or being unable to use this channel sufficiently will not be accepted. The following strategies are generally recommended to municipalities which want to use social media in city marketing activities;

- Designing the social media strategy in the direction of the purposes of city marketing,

- Designing the social media strategies as integrated with the traditional media tools,

- Continuously updating the page,

- In the contents, giving weight to visual and audial elements prepared by professionals,

- Focusing on viral contents,

- Managing the social media account by someone having good command of the information relevant to the city.

\section{Method}

Within the scope of this study that is performed in order to learn the use of social media in city marketing, 30 metropolitan municipalities in Turkey had been selected as institutions which take or required to take active duty in the process of publicity and marketing of the cities. Within this scope, the contents shared by 30 metropolitan municipalities in between 01-30.09.2016 on their official social media accounts had been examined. Within the scope of the research, first it had been entered in the official web sites of the municipalities and then it had been accessed to their social media accounts. Facebook, Twitter, Instagram and YouTube had been selected as social media channels. Among the contents shared by the municipalities, the contents relevant to natural, touristic, cultural and historical etc. elements of the city and the contents of artistic, cultural and sportive events realized in the city have been assessed as content within the scope of publicity, and the numbers of these contents have been considered. Content analysis method has been applied in the research.

\section{Findings}

In this section, the account statuses of metropolitan municipalities on social media channels such as Facebook, Twitter, Instagram and YouTube, their follower numbers on these channels, and their total sharings and sharings for publicity on these channels in between 01-30.09.2016 are being examined. ${ }^{1}$
Table 1: Social Media Account Information Statuses of Metropolitan Municipalities

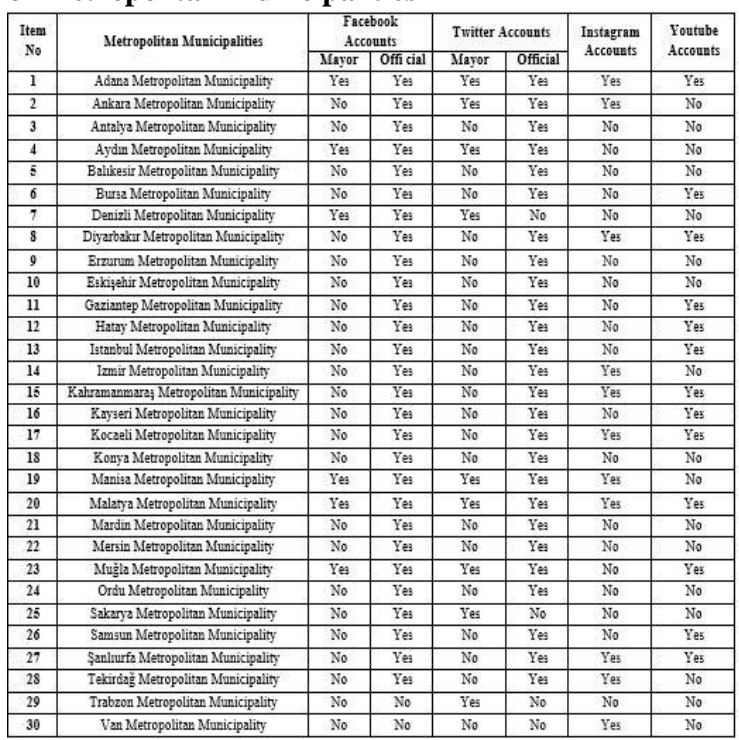

Resource: Table composed by author (01/10/2016)

In Table 1, the social media account information statuses of metropolitan municipalities are available. When the table is examined, it is observed that two metropolitan municipalities (Trabzon and Van) don't have official Facebook accounts, and that four metropolitan municipalities don't have official Twitter accounts. It is understood that the mayors of some of the metropolitan municipalities -which don't have Twitter accounts- are performing sharing on their Twitter accounts. It is also observed that nineteen metropolitan municipalities don't have official Instagram accounts, and that seventeen metropolitan municipalities don't have official YouTube accounts. When the memberships of social media channels -reaching to millions both across the world and across our country- are considered, the non-presence of metropolitan municipalities operating in Turkey cannot be thought.

\footnotetext{
${ }^{1}$ International Criminal Tribunal for the former Yugoslavia or ICTY, is a body of the United Nations established to prosecute serious crimes committed during the wars in the former Yugoslavia, and to try their perpetrators. The tribunal is an ad hoc court which is located in The Hague, Netherlands.
} 
Table 2: Social Media Account Information of Metropolitan Municipalities

\begin{tabular}{|c|c|c|c|c|c|c|}
\hline $\begin{array}{c}\text { Item } \\
\text { No }\end{array}$ & Metropolitan Muricipalities & $\begin{array}{l}\text { City } \\
\text { Population }\end{array}$ & $\begin{array}{l}\text { Number of } \\
\text { Facebook } \\
\text { Followers }\end{array}$ & $\begin{array}{l}\text { Number of } \\
\text { Twitter } \\
\text { Followers }\end{array}$ & $\begin{array}{l}\text { Number of } \\
\text { Instagram } \\
\text { Followers }\end{array}$ & $\begin{array}{c}\text { YouTube } \\
\text { Account } \\
\text { Subscribers }\end{array}$ \\
\hline 1 & Adana Metropolitan Nunicipality & 2.183 .167 & 83.097 & 23.516 & $\begin{array}{c}17.4 \\
\text { thousumds }\end{array}$ & 616 \\
\hline 2 & Ankara Metropolitzn Municipality & 5.270 .575 & 36.694 & 284.343 & $\begin{array}{c}12,3 \\
\text { thousands }\end{array}$ & - \\
\hline 3 & Antalya Metropolitan Muricipality & 2.288 .456 & 59.060 & 143.769 & No & - \\
\hline 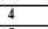 & Ay din Metropolitan Nunicipality & 053.506 & & & W & \\
\hline 5 & kesiir Mertol & 1.186 & 5.22 & . & No & - \\
\hline 6 & $\mathrm{ran} \mathrm{N}$ & 2.842 .547 & 27.401 & 132.745 & No & 804 \\
\hline 7 & politzen Mumicipality & 993.442 & 18.576 & Yok & No & - \\
\hline 8 & $\begin{array}{l}\text { Diyartzakr Netropolitan } \\
\text { Nunicipality }\end{array}$ & 1.654 .196 & 136.379 & 52.932 & No & 850 \\
\hline 9 & Erzarum Metropolitan Muricipality & 762.321 & 29.613 & 10.011 & No & - \\
\hline 10 & \begin{tabular}{|l} 
Eskizisehir Metropolitsn \\
Municipality
\end{tabular} & 826.716 & 32.798 & 1.540 & No & $\cdot$ \\
\hline 11 & \begin{tabular}{|l} 
Gaziantep Metropolitan \\
Municipality
\end{tabular} & 1.931 .836 & 136.288 & 39.034 & No & 920 \\
\hline 12 & Hatay Metropolitan Nunicipality & 421.766 & 32.825 & 5.511 & No & 245 \\
\hline 13 & \begin{tabular}{|l} 
Ittanbul Metropolitan Municipality \\
\end{tabular} & 14.657 .434 & 40.482 & 217.038 & No & 776 \\
\hline 14 & İzmir Metropolitan Municipality & 4.168 .415 & 66.309 & 17.528 & $\begin{array}{l}49,7 \\
\text { thousands }\end{array}$ & - \\
\hline 15 & $\begin{array}{l}\text { Kahramanmmaras Metropolitan } \\
\text { Muncipiplity }\end{array}$ & 1.341 .056 & 35.111 & 3.253 & $\begin{array}{c}14 \\
\text { thousunds } \\
\end{array}$ & 124 \\
\hline 16 & \begin{tabular}{|l} 
Kayseri Mertopolitam Municipality \\
\end{tabular} & 1.341 .056 & 24.548 & 19.507 & No & 373 \\
\hline 17 & Kocaeli Metropolitan Municipality & 1.780 .055 & 110.490 & 26.095 & $\begin{array}{c}10,5 \\
\text { thousands }\end{array}$ & 599 \\
\hline 18 & Koryz Metropolitan Muricipality & 2.130 .544 & 38.026 & 81.683 & No & - \\
\hline & Mancsang & 1.38 & & 7.64 & 9.888 & \\
\hline 20 & Malaztya Metopopolitan Mumicipality & & 9.799 & 8210 & 2714 & 227 \\
\hline 21 & Mardin Metropolitzn Municipality & 796.591 & 4.508 & 983 & No & \\
\hline 22 & \begin{tabular}{|l} 
Mersin 1. \\
\end{tabular} & 1.7452 & & & 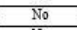 & \\
\hline 23 & & 908 & & & & 363 \\
\hline 24 & or & $702 x^{2}$ & & 3. & No & - \\
\hline 25 & & & & & No & $\because$ \\
\hline 26 & Municipality & 1.279 .884 & 3.474 & 405 & No & 29 \\
\hline 27 & $\begin{array}{l}\text { Somlurfa Metropolitan } \\
\text { Municipality }\end{array}$ & 1.892320 & 15.523 & 13.587 & 1.244 & - \\
\hline 28 & Tekirdaj Metropolitan Manicipality & 937.910 & 20.015 & 8.111 & 2803 & - \\
\hline 29 & Trabzon Metropolitan Municipalify & 768.417 & Yok & $6.013^{\circ}$ & No & - \\
\hline 30 & Van Metropolitan Muricipality & 1.096397 & Yok & Yok & 38 & \\
\hline
\end{tabular}

Resource: Table composed by author (10/10/2016)

* Belongs to mayors of metropolitan municipalities.

In Table 2, the populations of metropolitan municipalities as per address based population registration system for the year 2015 and their social media account information are available. When the table is examined, Istanbul is ranking the first by 14.657.434 individuals in terms of population. Also in terms of Facebook followers, Diyarbakir is ranking the first with 136.379 followers. Ankara has 284.343 followers on Twitter. And in terms of Instagram followers, Izmir is ranking the first with 49.7 thousand followers. Finally, Gaziantep has 920 YouTube subscribers. When the figures are considered, it is observed that the numbers of followers and subscribers are as few as not be compared with the populations of especially the largest three cities. It is being thought that these figures will increase through the provision by the metropolitan municipalities of information that will facilitate the daily activities of citizens as daily routine issues being in the first place over social channels of information.
Table 3: Facebook Sharings of Metropolitan Municipalities

\begin{tabular}{|c|l|c|c|}
\hline $\begin{array}{c}\text { Item } \\
\text { No }\end{array}$ & \multicolumn{1}{|c|}{ Metropolitan Municipalities } & $\begin{array}{c}\text { Number of } \\
\text { Tweets with } \\
\text { Promotional } \\
\text { Content }\end{array}$ & $\begin{array}{c}\text { Total Shared } \\
\text { Content }\end{array}$ \\
\hline $\mathbf{1}$ & Adana Metropolitan Municipality & 24 & 109 \\
\hline $\mathbf{2}$ & Ankara Metropolitan Municipality & 6 & 8 \\
\hline $\mathbf{3}$ & Antalya Metropolitan Municipality & 121 & 188 \\
\hline $\mathbf{4}$ & Aydun Metropolitan Municipality & 11 & 27 \\
\hline $\mathbf{5}$ & Ballkesir Metropolitan Municipality & 24 & 43 \\
\hline $\mathbf{6}$ & Bursa Metropolitan Municipality & 48 & 126 \\
\hline $\mathbf{7}$ & Denizli Metropolitan Municipality & 17 & 31 \\
\hline $\mathbf{8}$ & Diyarbakrm Metropolitan Municipality & 27 & 76 \\
\hline $\mathbf{9}$ & Erzurum Metropolitan Municipality & 15 & 48 \\
\hline $\mathbf{1 0}$ & Eskisehir Metropolitan Municipality & 44 & 82 \\
\hline $\mathbf{1 1}$ & Gaziantep Metropolitan Municipality & 40 & 86 \\
\hline $\mathbf{1 2}$ & Hatay Metropolitan Municipality & 56 & 97 \\
\hline $\mathbf{1 3}$ & Istanbul Metropolitan Municipality & 67 & 131 \\
\hline $\mathbf{1 4}$ & Izmir Metropolitan Municipality & 42 & 87 \\
\hline $\mathbf{1 5}$ & Kahramanmaras Metropolitan Municipality & 60 & 127 \\
\hline $\mathbf{1 6}$ & Kayseri Metropolitan Municipality & 28 & 67 \\
\hline $\mathbf{1 7}$ & Kocaeli Metropolitan Municipality & 35 & 81 \\
\hline $\mathbf{1 8}$ & Konya Metropolitan Municipality & 46 & 106 \\
\hline $\mathbf{1 9}$ & Manisa Metropolitan Municipality & 86 & 378 \\
\hline $\mathbf{2 0}$ & Malatya Metropolitan Municipality & 15 & 53 \\
\hline $\mathbf{2 1}$ & Mardin Metropolitan Municipality & 6 & 20 \\
\hline $\mathbf{2 2}$ & Mersin Metropolitan Municipality & 62 & 246 \\
\hline $\mathbf{2 3}$ & Muğla Metropolitan Municipality & 27 & 54 \\
\hline $\mathbf{2 4}$ & Ordu Metropolitan Municipality & 19 & 50 \\
\hline $\mathbf{2 5}$ & Sakarya Metropolitan Municipality & 54 & 118 \\
\hline $\mathbf{2 6}$ & Samsun Metropolitan Municipality & 0 & 2 \\
\hline $\mathbf{2 7}$ & Sanlurfa Metropolitan Municipality & 43 & 115 \\
\hline $\mathbf{2 8}$ & Tekirdağ Metropolitan Municipality & 16 & 73 \\
\hline $\mathbf{2 9}$ & Trabzon Metropolitan Municipality & 0 & 0 \\
\hline $\mathbf{3 0}$ & Van Metropolitan Municipality & 0 & 0 \\
\hline $\mathbf{2}$ & & & \\
\hline
\end{tabular}

Resource: Table composed by author $(01 / 10 / 2016)$

It contains data between 01-30.09.2016.

In Table 3, there are Facebook sharing of metropolitan municipalities in between 01-30.09.2016. When the table is examined, it is being observed that three metropolitan municipalities which share content the most on Facebook are Manisa with 378 contents, Mersin with 246 contents and Antalya with 188 contents. Moreover, three metropolitan municipalities sharing content the most are Antalya with 121 contents, Manisa with 86 contents and Istanbul with 67 contents. When the publicity focused contents shared on Facebook by metropolitan municipalities are considered, it had been determined that they are visuals of activities for increasing the life quality of inhabitants of the city. These are relevant to social and cultural events performed in the city and the natural, historical and touristic elements of the city. Today, Facebook has the most followers among social media networks. In this direction and in the context of city marketing, Turkish metropolitan municipalities should increase their number of followers through publicity focused sharings and should enable their followers to share such contents on their pages. 
Table 4: Twitter Sharings of Metropolitan Municipalities

\begin{tabular}{|c|c|c|c|}
\hline $\begin{array}{l}\text { Item } \\
\text { No }\end{array}$ & Metropolitan Municipalities & $\begin{array}{c}\text { Number of } \\
\text { Tweet with } \\
\text { Promotional } \\
\text { Content }\end{array}$ & $\begin{array}{l}\text { Total Shared } \\
\text { Tweet Number }\end{array}$ \\
\hline 1 & Adana Metropolitan Municipality & 25 & 105 \\
\hline 2 & Ankara Metropolitan Municipality & 8 & 12 \\
\hline 3 & Antalya Metropolitan Mumicipality & 233 & 310 \\
\hline 4 & Aydm Metropolitan Municipality & 13 & 26 \\
\hline 5 & Balikesir Metropolitan Municipality & 39 & 156 \\
\hline 6 & Bursa Metropolitan Municipality & 42 & 205 \\
\hline 7 & Denizli Metropolitan Municipality & 0 & 0 \\
\hline 8 & Diyarbakar Metropolitan Municipality & 17 & 76 \\
\hline 9 & Erzurum Metropolitan Municipality & 12 & 43 \\
\hline 10 & Eskişehir Metropolitan Municipality & 6 & 20 \\
\hline 11 & Gaziantep Metropolitan Municipality & 34 & 127 \\
\hline 12 & Hatay Metropolitan Municipality & 36 & 71 \\
\hline 13 & Istanbul Metropolitan Municipality & 160 & 374 \\
\hline 14 & İzmir Metropolitan Municipality & 30 & 79 \\
\hline 15 & Kahramanmaras Metropolitan Municipality & 56 & 149 \\
\hline 16 & Kayseri Metropolitan Municipality & 55 & 92 \\
\hline 17 & Kocaeli Metropolitan Municipality & 37 & 98 \\
\hline 18 & Konya Metropolitan Municipality & 49 & 106 \\
\hline 19 & Manisa Metropolitan Municipality & 50 & 383 \\
\hline 20 & Malatya Metropolitan Municipality & 26 & 104 \\
\hline 21 & Mardin Metropolitan Municipality & 7 & 21 \\
\hline 22 & Mersin Metropolitan Municipality & 0 & 0 \\
\hline 23 & Muğla Metropolitan Municipality & 15 & 24 \\
\hline 24 & Ordu Metropolitan Municipality & 10 & 47 \\
\hline 25 & Sakarya Metropolitan Municipality & 32 & 139 \\
\hline 26 & Samsun Metropolitan Municipality & 11 & 34 \\
\hline 27 & Şanlurfa Metropolitan Municipality & 116 & 474 \\
\hline 28 & Tekirdağ Metropolitan Municipality & 6 & 48 \\
\hline 29 & Trabzon Metropolitan Mumicipality & 4 & 25 \\
\hline 30 & Van Metropolitan Municipality & 0 & 0 \\
\hline
\end{tabular}

It contains data between 01-30.09.2016.

In Table 4 , there are the Twitter sharings of metropolitan municipalities in between 01-30.09.2016 given as total and publicity focused. When the table is examined, the metropolitan municipalities sharing content the most within the specified period had been Sanliurfa with 474 contents, Manisa with 383 contents and Istanbul with 374 contents. When the publicity focused Twitter sharings of metropolitan municipalities are considered, Antalya has 233 contents, Istanbul has 160 contents and Sanliurfa has 116 contents. When the contents shared by metropolitan municipalities on Twitter are considered, it is observed that mostly the contents on Facebook are shared. It is required for the metropolitan municipalities to be present also on Twitter to feed their followers with visuals and texts.
Table 5: Instagram Sharings of Metropolitan Municipalities

\begin{tabular}{|c|c|c|c|}
\hline $\begin{array}{l}\text { Item } \\
\text { No }\end{array}$ & Metropolitan Municipalities & $\begin{array}{c}\text { Number of } \\
\text { Shares with } \\
\text { Promotional } \\
\text { Content }\end{array}$ & $\begin{array}{l}\text { Total } \\
\text { Content } \\
\text { Shared }\end{array}$ \\
\hline 1 & Adana Metropolitan Municipality & 25 & 151 \\
\hline 2 & Ankara Metropolitan Municipality & 70 & 165 \\
\hline 3 & Antalya Metropolitan Municipality & - & - \\
\hline 4 & Aydn Metropolitan Municipality & - & - \\
\hline 5 & Ballkesir Metropolitan Municipality & - & - \\
\hline 6 & Bursa Metropolitan Municipality & - & - \\
\hline 7 & Denizli Metropolitan Municipality & - & - \\
\hline 8 & Diyarbakur Metropolitan Municipality & - & - \\
\hline 9 & Erzurum Metropolitan Municipality & - & - \\
\hline 10 & Eskişehir Metropolitan Municipality & - & - \\
\hline II & Gaziantep Metropolitan Municipality & - & - \\
\hline 12 & Hatay Metropolitan Municipality & - & - \\
\hline 13 & İtanbul Metropolitan Municipality & - & - \\
\hline 14 & Izmir Metropolitan Municipality & 20 & 32 \\
\hline 15 & Kahramanmaras Metropolitan Municipality & 6 & 19 \\
\hline 16 & Kayseri Metropolitan Municipality & - & \\
\hline 17 & Kocaeli Metropolitan Municipality & 0 & 8 \\
\hline 18 & Konya Metropolitan Municipality & - & - \\
\hline 19 & Manisa Metropolitan Municipality & 0 & 26 \\
\hline 20 & Malatya Metropolitan Municipality & 1 & 1 \\
\hline 21 & Mardin Metropolitan Municipality & - & - \\
\hline 22 & Mersin Metropolitan Municipality & - & - \\
\hline 23 & Muğla Metropolitan Municipality & - & - \\
\hline 24 & Ordu Metropolitan Municipality & - & - \\
\hline 25 & Sakarya Metropolitan Municipality & - & - \\
\hline 26 & Samsun Metropolitan Municipality & - & - \\
\hline 27 & Șanluurfa Metropolitan Municipality & 9 & 21 \\
\hline 28 & Tekirdağ Metropolitan Municipality & 0 & 6 \\
\hline 29 & Trabzon Metropolitan Municipality & - & - \\
\hline 30 & Van Metropolitan Municipality & 0 & 0 \\
\hline
\end{tabular}

Resource: Table composed by author (01/10/2016)

It contains data between 01-30.09.2016

In Table 5, there is Instagram sharing of metropolitan municipalities between 01-30.09.2016. As it will be observed from the table, only 10 of the metropolitan municipalities have Instagram accounts. This social network, where the followers mainly share visual contents, is being encountered as a channel on which the visuals and publicity videos relevant to the city are required to be shared greatly. When the table is examined, it is observed that Ankara and Adana are the metropolitan municipalities sharing content the most. Also, in terms of sharing publicity focused contents, again these two metropolitan municipalities are coming to the forefront. But when the contents shared are examined, it is observed that they are mostly focused on celebrations, meetings and openings. Instagram is a social network that, the metropolitan municipalities should definitely use with its user numbers reaching to millions in Turkey. 
Table 6: YouTube Sharings of Metropolitan Municipalities

\begin{tabular}{|c|c|c|c|}
\hline $\begin{array}{l}\text { Item } \\
\text { No }\end{array}$ & Metropolitan Municipalities & $\begin{array}{l}\text { Number of Shares } \\
\text { with Promotional } \\
\text { Content }\end{array}$ & $\begin{array}{l}\text { Total Shared } \\
\text { Content }\end{array}$ \\
\hline 1 & Adana Metropolitan Municipality & $\begin{array}{c}\text { Content } \\
14\end{array}$ & 32 \\
\hline 2 & Ankara Metropolitan Municipality & - & - \\
\hline 3 & Antalya Metropolitan Municipality & - & - \\
\hline 4 & Aydun Metropolitan Municipality & - & 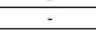 \\
\hline 5 & Balkesir Metropolitan Mumicipality & - & - \\
\hline 6 & Bursa Metropolitan Municipality & 0 & 0 \\
\hline 7 & Denizli Metropolitan Mumicipality & - & - \\
\hline 8 & Divarbakrr Metropolitan Municipality & 0 & 1 \\
\hline 9 & Erzunum Metropolitan Municipality & - & - \\
\hline 10 & Eskisehir Metropolitan Municipality & . & - \\
\hline 11 & Gaziantep Metropolitan Municipality & 2 & 3 \\
\hline 12 & Hatay Metropolitan Muricipality & 0 & 3 \\
\hline 13 & Istanbul Metropolitan Municipality & 0 & 1 \\
\hline 14 & Izmir Metropolitan Municipality & 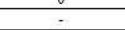 & 1 \\
\hline$\frac{14}{15}$ & Kahramanmaras Metropolitann Mumicipality & 2 & $\overline{12}$ \\
\hline 16 & Kayseri Metropolitan Municipality & 0 & 0 \\
\hline 17 & Kocaeli Metropolitan Municipality & $\frac{0}{1}$ & $\frac{0}{2}$ \\
\hline 18 & Konya Metropolitan Municipality & - & 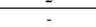 \\
\hline 19 & Manisa Metropolitan Municipality & $\because$ & - \\
\hline 20 & Malatya Metropolitan Municipality & 0 & 0 \\
\hline 21 & Mardin Metropolitan Municipality & - & - \\
\hline 22 & Mersin Metropolitan Municipality & - & - \\
\hline 23 & Muğla Metropolitan Municipality & 0 & 0 \\
\hline 24 & Ordu Metropolitan Municipality & 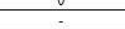 & - \\
\hline 25 & Sakarya Metropolitan Municipality & - & \\
\hline 26 & Samsun Metropolitan Muricipality & 0 & 0 \\
\hline 27 & Sanlurfa Metropolitan Municipality & 1 & 2 \\
\hline 28 & Tekirdağ Metropolitan Municipality & 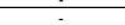 & 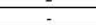 \\
\hline 29 & Trabzon Metropolitan Municipality & - & - \\
\hline 30 & Van Metropolitan Municipality & 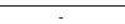 & - \\
\hline
\end{tabular}

Resource: Table composed by author $(01 / 10 / 2016)$

It contains data between 01-30.09.2016.

Finally, in Table 6, the YouTube sharing figures of metropolitan municipalities in between 01-30.09.2016 are available. When the table is examined, it is observed that only 13 metropolitan municipalities have YouTube accounts. It is thought that other municipalities which don't consider to be present in this social channel -that has millions of users in the world- will not be able to have reasonable grounds. When the table is examined, it is observed that the metropolitan municipality which had shared the most videos in between the specified dates is Adana with 32 videos, and it is being followed by Kahramanmaraş with 11 videos. Also when the publicity focused video sharings are considered, Adana is ranking first. Adana metropolitan municipality's videos for introducing the city such as festivals etc. are coming to the forefront.

\section{Conclusion}

Social media has extremely significant pluses when compared to traditional communication means with its advantages such as being able to reach to large masses, interacting with the target audience, getting fast feedback, cost etc. In this sense, the local administrations such as municipalities and governorates should involve in their city marketing activities. The following results and recommendations have been revealed within the scope of this study that is realized in order to determine how the 30 metropolitan municipalities use social media by sharing publicity focused contents within the scope of city marketing activities;

- In the examination performed within the scope of the research, with 136.379 followers, Diyarbakir metropolitan municipality is ranking the first among 30 metropolitan municipalities in respect of Facebook followers. Also, Ankara metropolitan municipality is ranking the first with 284.343 individuals in respect of number of Twitter followers. And in terms of Instagram followers, Izmir metropolitan municipality is ranking the first with 49.7 thousand followers. Finally, Gaziantep metropolitan municipality has 920 YouTube subscribers. When the figures are considered, it is observed that the numbers of followers and subscribers are as few as not to be compared with the populations of especially the largest three cities.

- It is being observed that the three metropolitan municipalities which share content the most on Facebook are Manisa with 378 contents, Mersin with 246 contents and Antalya with 188 contents. Moreover, in the ranking of three metropolitan municipalities sharing publicity focused content the most, it is observed that they are Antalya with 121 contents, Manisa with 86 contents and Istanbul with 67 content.

- When the Twitter sharings of 30 metropolitan municipalities are considered, the metropolitan municipalities sharing content the most within the research period had been Sanliurfa with 474 contents, Manisa with 383 contents and Istanbul with 374 contents. When the publicity focused Twitter sharings are considered, Antalya has 233 contents, Istanbul has 160 contents and Sanliurfa has 116 contents.

- Also in the Instagram sharings of metropolitan municipalities, it is being observed that Ankara and Adana metropolitan municipalities are sharing the most content. Plus, in sharing of publicity focused contents, again these two metropolitan municipalities are coming to the forefront.

- Then by the help of research, it is observed that only 13 metropolitan municipalities have YouTube accounts, and the metropolitan municipality sharing the most video is Adana with 32 videos. That is followed by Kahramanmaraş with 11 videos. When the publicity focused video sharings are considered, Adana is ranking the first.

- For the municipalities to effectively benefit from social media in city marketing, it is required for the accounts to be managed by professional employees directly affiliated to the administration of the city and for them to respond the questions and critics as soon as possible. 
- When the sharings of metropolitan municipalities on social media channels are examined, it had been revealed that the contents are relevant to meetings, openings, visits, celebrations and etc. The metropolitan municipalities to perform sharings also on other subjects besides these contents will contribute to the increase of number of followers.

- For the municipalities to effectively use social media in the context of city marketing, they are required to frequently share the historical, touristic, cultural values of the city with visual contents. Again, all kinds of social, artistic, cultural and sportive events to be realized in the city are required to be shared with the followers with visual and viral contents.

Consequently, it is affecting the behaviors of users of social media -that increases its number of users each day- both at the point of goods and services and at the point of touristic products. Thus, it has become easier for the local administrations to communicate their touristic, historical and cultural values through official accounts to attract the attention of masses. It is not possible to explain and understand the attitudes of local administrations which stay away from these social media channels which have millions of followers and uses, and which don't effectively use these channels despite willing to attract more tourists and investors to their cities.

\section{REFERENCES}

Altunbaş, H. (2007) Pazarlama İletişimi ve Şehir Pazarlaması "Şehirlerin Markalaşması". Selçuk İletişim, 4, 4, 2007.

Bozkurt, H.H. (2013) Halkla İlişkiler Uygulamacıları İçin Edirne İli Tanıtım Materyallari. Sosyal Ve Beşeri Bilimler Dergisi Cilt 5, No 2, 2013 ISSN: 13098012 (Online).

Criado, J. Ignacio, Sandoval-Almazan, Rodrigo. Gil-Garcia, J. Ramon (2013) Government innovation through social media. Government Infotmatin Quarterly 30 (2013) 319-326.
Çalışır, G. (2015) Halkla İlişkiler Uygulaması Olarak Belediyelerde Sosyal Ağların Kullanımı. Çağdaş Yerel Yönetimler, Cilt 24 Sayı 4 Ekim 2015, s.59-93.

Goovaerts, P. Biesbroecka, H. Van, T, Van T. (2014) Measuring the effect and efficiency of city marketing Procedia Economics and Finance 12 ( 2014 ) $191-198$.

Gulbahar, O. M. and Yildırım, F. (2015) Marketing Efforts Related to Social Media Channels and Mobile Application Usage in Tourism: Case Study in Istanbul. Procedia - Social and Behavioral Sciences 195 ( 2015 ) 453 462 .

Jacobsen, J. Steen K. and Munar, A. M. (2012) Tourist information search and destination choice in a digital age. Tourism Management Perspectives 1 (2012) 39-47

Howard, Anne E (2012)Connectıng With Communities, How Local Government is Using Social Media to Engage with Citizens.http://www.governanceinstitut e.edu.au/magma/media/upload/ckeditor /files/1353548699_ConConnect_Com munities_ANZSIGACELG_August_2012.pdf (18.07.2016).

İnal M. E. İri R., H. Türkmen H. (2011). Şehir Pazarlamasında Bilinirliğin Önemi: Niğde Yöresinin Bilinirliğinin Ölçülmesine Yönelik Bir Araştırma. Niğde Üniversitesi İ̈BF Dergisi, 2011, Cilt: 4, Say1: 1, s. 81-96

Kaplan, A. M. and Haenlein, M. (2010). "Users Of The World, Unite! The Challenges And Opportunities Of Social Media", Business Horizons, 59-68.

Kavaratzis M. and Ashworth G.J. (2007) Partners in coffeeshops, canals and commerce: Marketing the city of Amsterdam. Cities, Vol. 24, No. 1, p. 16-25, 2007. _ 2006 Elsevier Ltd. 
Ketter, E. (2016) Destination image restoration on facebook: The case study of Nepal's Gurkha Earthquake. Journal of Hospitality and Tourism Management 28 (2016) 66-72.

Mainka A. H. S., Stock W., Peters G. I. (2014) Government and Social Media: A Case Study of 31 Informational World Cities. 2014 47th Hawaii International Conference on System Science. https://www.phil-fak.uniduesseldorf.de/fileadmin/Redaktion/Ins titute/Informationswissenschaft/heck/M ainka_ua_HICSS_2014_Publikation_0 1.pdf (25.08.2016).

Mossberger, K. Wu, Y, Crawford, J. (2013) Connecting citizens and local governments? Social media and interactivity in major U.S. cities. Government Information Quarterly 30 (2013) 351-358.

Sevin H. E. (2014) Understanding cities through city brands: City branding as a social and semantic network. Cities 38 (2014) 47-56.

Socialbakers (2016) Free social media statistics directory https://www.socialbakers.com/statistics /google-plus/profiles/turkey/ (09.09.2016).

Tarhan, A. (2012) Büyükşehir Belediyelerinin Sosyal Medya Uygulamalarına Halkla İlişkiler Modellerinden Bakmak. İletişim Kuram ve Araştırma Dergisi Sayı 35 /Güz 2012

Wearesocial (2016) Digital in 2016. http://wearesocial.com/uk/specialreports/digital-in-2016 (06.09.2016).Žiković, S. 2006. Implications of measuring $\mathrm{VaR}$ using historical simulation; An example of Zagreb Stock Exchange index CROBEX in J. Roufagalas (Ed.), Resource allocation and institutions: Explorations in economics, finance and law. 367-389.

Xiang. Z, and Gretzel, U. (2010) Role of social media in online travel information search. Tourism Management 31 (2010) 179-188.
Zhou, L, and Wang, T. (2014) Social media: A new vehicle for city marketing in China. Cities 37 (2014) 27-32 